\title{
TINKLININKŲ DOMINUOJANČIOS RANKOS ŽASTO AMPLITUDŽIŲ, SUKAMŲJŲ RAUMENŲ JĖGOS BEI PETIES DINAMINIO STABILUMO SĄSAJOS SU SKAUSMU
}

\author{
Gaivilè Kurtinaityte் ${ }^{1}$, Aistė Jakubauskienè $\dot{1}^{1,2}$ \\ ${ }^{1}$ Vilniaus universiteto Medicinos fakulteto Sveikatos moksly institutas, \\ ${ }^{2}$ Vilniaus universiteto ligoninès Santaros kliniku Reabilitacijos, fizinès ir sporto \\ medicinos centras
}

Raktažodžiai: tinklinis, dominuojanti pusè, peties traumos, skausmas, traumų prevencija.

\begin{abstract}
Santrauka
Tyrimo tikslas - išanalizuoti tinklininkų dominuojančios rankos žasto amplitudžių, sukamųjų raumenų jègos bei peties dinaminio stabilumo sąsajas su skausmu. Tyrime dalyvavo 40 tinklininkų (amžius $-28,45 \pm 7,55$ metai), žaidžiančių mėgejiškai (tinklinio žaidimo patirtis $-8,65 \pm 5,34$ metai). Tiriamieji pagal apklausos duomenis buvo suskirstyti i dvi grupes: jaučiantys skausmą peties srityje $(n=21)$ ir nejaučiantys $(n=19)$. Tyrimo metu buvo išmatuoti tinklininkų dominuojančios rankos parametrai: aktyvios žasto judesių amplitudès (lenkimas, sukimas i vidų ir ị išorę), žasto vidinių ir išorinių sukamųjų raumenų maksimali izometrinè jèga, dinaminis peties sąnario stabilumas. Skausmas, jaučiamas pirmosios grupès respondentų, klinikinių provokacinių testų metu ivvertintas vizualine analogine skale. Dominuojančios rankos žasto sukimo ị vidų amplitude, išorinių sukamujjų raumenų izometrinè jèga bei peties sąnario dinaminio stabilumo testų rezultatai buvo mažesni skausmą jaučiančių tinklininkų grupẻje. Rastos sąsajos tarp peties skausmo stiprumo klinikinių provokacinių testų metu ir žasto judesių amplitudžių (lenkimo ir sukimo ị vidų).
\end{abstract}

\section{Ivadas}

Tinklinio užsièmimų metu pečių lanko sritis yra nuolat alinama pasikartojančių judesių, tokių kaip kamuolio padavimas, smūgiavimas ar atmušimas. Tinklininkų peties sąnario traumos sudaro apie 19 procentų visų sužalojimų ir dažniausiai būna ilgai trunkančio, pakartotinio fizinio krūvio pasekmè [1]. Sudètinga įvertinti šių lètinių pažeidimų dažnị, paplitimą ir poveikị atletų fizinei būklei, todèl mokslinèje literatūroje pateiktos rekomendacijos, kuriose akcentuota, kad pagrindinis simptomas, $i$ kurị reikètų atsižvelgti - skausmas, patirtas tyrimo ar sportinès veiklos metu. Kartu siūloma vertinti ir tokių funkcinių rodiklių pokyčius: peties sąnario nestabilumą, amplitudžių ar aplinkinių raumenų jègos sumažejimą, judesių vikrumą, paslankumą ir greiți.

Tinklinyje dažni metimo judesiai virš galvos, todèl pastebimas dominuojančios rankos žasto lenkimo, sukimo ị vidų sumažejimas ir padidejjusi sukimo ị išorę amplitudè. Sumažéjusi vidinè ir bendra žasto sukimo amplitudè po metimo ar atmušimo susijusi su išorinių sukamujų raumenų žalojimu ekscentrinio susitraukimo metu, kai bandoma sulètinti rankos ašinį sukimąsi. Norint laiku imtis prevencinių priemonių lètiniams sužalojimams išvengti bei siekiant ịvertinti sportininko pažangą treniruojantis arba būklę patyrus traumą, turètų būti taikomas sukamosios manžetès raumenų jègos matavimas [2]. Dèl žasto judesių amplitudžių, raumenų ar kapsulès itampos pokyčiu sutrikdoma peties biomechanika, galinti paskatinti pažeidimų, tokių kaip peties ankštumo sindromas, sąnario nestabilumas ar žasto panirimas, išsivystymą [3].

Peties skausmas ar traumos turi įtakos ir visai judesio kinetinei grandinei smūgio metu. Dažnai pastebima, kad šiuos pažeidimus patyrusių sportininkų liemens kontrolè būna prastesnè. Atmušant kamuolị, svarbi ne tik judesio amplitudẻ bei petị stabilizuojančių raumenų aktyvacija, bet ir visos kinetinès grandinès koordinuotas ịsitraukimas ị judesị, kadangi raumeninis korsetas atlieka jègos perdavimo iš apatinès galūnès pečių lankui funkciją [4]. Visų kinetinès grandinès raumenų grupių veiklos koordinacijos įvertinimui taikomi standartizuoti viršutinès galūnès dinaminio stabilumo ir pusiausvyros testai, kurių pagalba galima ištirti sportininkų peties funkcinę būklę, nustatyti ryškius pakitimus, silpnybes ir palyginti rezulta- 
tus su tinklininkams rekomenduojamomis normomis $[5,6]$.

Remiantis kelių specialiujų testų kombinacija, peties sąnarį supančių raumenų jègos ir amplitudžių matavimais, galima įvertinti tinklininkų fizinę būklę bei pastebèti pirmuosius galimo traumavimo požymius, atsiradusius dèl lètinio funkcijos sutrikimo [2,5]. Dažnai sportininkai, nors ir pajunta pirmaji pažeidimo simptomą - skausmą, nelinkę nutraukti treniruočių ir kreiptis ị sveikatos priežiūros specialistus. Vèliau išsivysto lètinès traumos, po kurių reikalingas ilgas gydymo ir atsigavimo laikotarpis. Ypač pažeidus pečių lanko sritị, reikšmingai sumažèja žaidèjo meistriškumas ir gali pablogèti gyvenimo kokybė [1].

O. Kilic ir kiti autoriai (2017) siūlo atlikti daugiau tyrimų, skirtų išanalizuoti šių sportininkų funkcinès būklès rodiklius, i kuriuos atsižvelgiant ateityje būtų galima rekomenduoti kuo veiksmingesnes peties traumų ir skausmo prevencijos priemones [7].

Tyrimo tikslas - išanalizuoti tinklininkų dominuojančios rankos žasto amplitudžių, peties sukamujjų raumenų jẻgos bei dinaminio stabilumo sąsajas su skausmu.

\section{Tyrimo objektas ir metodika}

Tyrimas vyko Vilniaus universiteto Medicinos fakulteto Sveikatos mokslų instituto Reabilitacijos, fizinès ir sporto medicinos katedroje ir Vilniaus universiteto Sveikatos ir sporto centre nuo 2018 metų lapkričio iki 2019 metų gegužès mėnesio. Tyrime dalyvavo 18-50 metų amžiaus tinklininkai (19 vyrų ir 21 moteris) savanoriai, žaidžiantys mejgejjiškai. Tiriamujų amžiaus vidurkis buvo $28,45 \pm 7,55$ metai, vidutiné tinklinio žaidimo patirtis $-8,65 \pm 5,34$ metai (mažiausiai - 2 , daugiausiai - 28 metai)

Tyrimui buvo atrinkti tiriamieji, atitikę šiuos kriterijus: pateko ị 18-50 metu amžiaus grupę, nebuvo nutraukę sportinès veiklos testavimo metu ir mènesi prieš tyrimą, žaidè tinklinị ne mažiau kaip 2 metus. Neįtraukti ị tyrimą tie,

1 lentelè. Bendroji tiriamujų charakteristika p - reikšmingumo lygmuo, $S N$ - standartinis nuokrypis

\begin{tabular}{|c|c|c|c|c|}
\hline \multirow[b]{2}{*}{ Rodiklis } & \multirow[b]{2}{*}{$\begin{array}{c}\text { Visi }(n=40) \\
\text { (vidurkis } \\
\pm \text { SN) }\end{array}$} & \multicolumn{2}{|c|}{ Grupė (vidurkis \pm SN) } & \multirow[b]{2}{*}{ p } \\
\hline & & $\begin{array}{c}\text { skausmą } \\
\text { jaučiantys } \\
(n=21)\end{array}$ & $\begin{array}{c}\text { skausmo } \\
\text { nejaučiantys } \\
(n=19) \\
\end{array}$ & \\
\hline Amžius, m. & $28,45 \pm 7,55$ & $30,62 \pm 8,14$ & $26,05 \pm 6,21$ & 0,396 \\
\hline Ūgis, cm & $179,25 \pm 8,76$ & $\begin{array}{l}179,38 \\
\pm 9,03\end{array}$ & $179,11 \pm 8,29$ & 0,997 \\
\hline Svoris, kg & $75,33 \pm 11,20$ & $74,19 \pm 11,28$ & $.76,58 \pm 11,29$ & 0,934 \\
\hline Žaidimo metai & $8,65 \pm 5,34$ & $8,29 \pm 4,83$ & $9,05 \pm 5,97$ & 0,809 \\
\hline $\begin{array}{l}\text { Žaidimo val. } \\
\text { per sav. }\end{array}$ & $5,66 \pm 2,42$ & $5,31 \pm 1,79$ & $6,08 \pm 2,96$ & 0,218 \\
\hline
\end{tabular}

kurie patyre peties sąnario traumą ar pradèjo jausti skausmą mažiau nei prieš tris mėnesius iki testavimo, turejo gretutinių traumų ar susirgimų, galëjusių trikdyti tyrimo eigą, nesutikę dalyvauti tyrime.

Tyrimui naudota anketinė apklausa, kurios tikslas buvo išsiaiškinti tiriamujjų bendrąsias kūno charakteristikas, treniravimosi ypatybes, patirtas peties srities traumas ir skausmą. Tiriamieji pagal apklausos duomenis buvo suskirstyti i dvi grupes: jaučiantieji skausmą peties srityje $(n=21)$ ir skausmo nejaučiantieji $(n=19)$. Klinikiniai provokaciniai testai (Hawkins-Kennedy, Neer, „Tuščios skardinès“) atlikti siekiant nustatyti peties skausmo lygi dèl galimo sukamosios manžetès raumenų pažeidimo. Skausmo stiprumas testų metu ịvertintas naudojant vizualinę analoginę skalę (toliau - VAS). Žasto aktyvių judesių amplitudès išmatuotos mechaniniu goniometru: žasto lenkimas matuojamas tiriamajam seddint, o sukamujų judesių amplitudès ịvertinamos gulint ant nuga-

2 lentelė. Dominuojančios rankos žasto aktyvių judesių amplitudžių palyginimas tarp grupių

p-reikšmingumo lygmuo, $S N$ - standartinis nuokrypis

\begin{tabular}{|l|c|c|c|}
\hline $\begin{array}{l}\text { Žasto judesiai } \\
\text { (laipsniais) }\end{array}$ & $\begin{array}{c}\text { Skausmą } \\
\text { jaučiančių } \\
\text { grupė, n=21 } \\
\text { (vidurkis } \pm \text { SN) }\end{array}$ & $\begin{array}{c}\text { Skausmo } \\
\text { nejaučiančių } \\
\text { grupė, n=19 } \\
\text { (vidurkis } \pm \text { SN) }\end{array}$ & $\boldsymbol{p}$ \\
\hline Žasto lenkimas & $171,81 \pm 15,07$ & $175,47 \pm 8,05$ & 0,339 \\
\hline $\begin{array}{l}\text { Žasto sukimas } \\
\text { i vidų }\end{array}$ & $42,71 \pm 8,83$ & $49,21 \pm 8,84$ & $\mathbf{0 , 0 4 3}$ \\
\hline $\begin{array}{l}\text { Žasto sukimas } \\
\text { i išorę }\end{array}$ & $93,29 \pm 10,99$ & $96,90 \pm 8,64$ & 0,259 \\
\hline
\end{tabular}

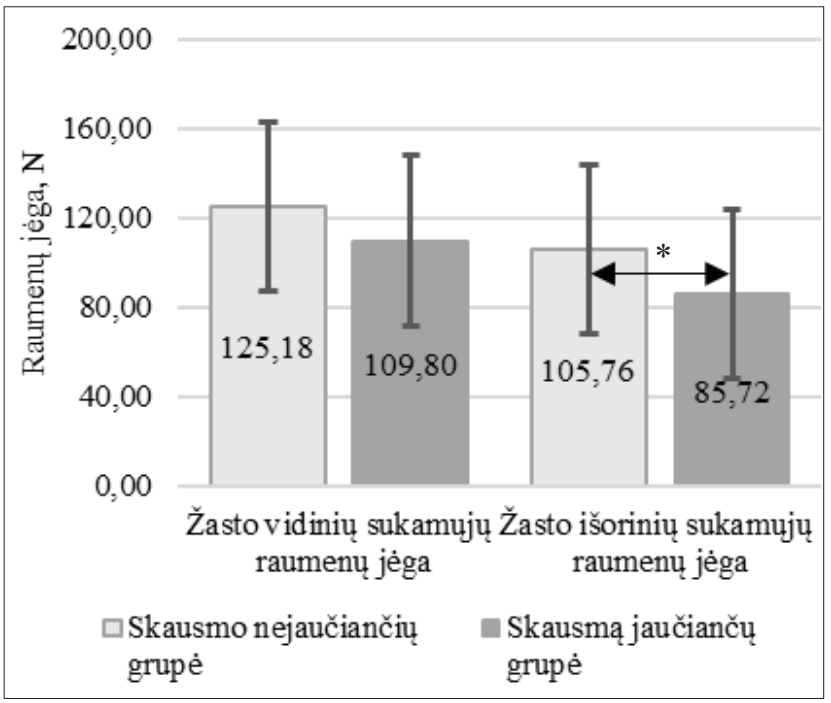

1 pav. Vidinių ir išorinių sukamųjų raumenų izometrinès jègos vidurkių skirtumai

* - statistiškai reikšmingas skirtumas tarp grupiu $(p<0,05)$ 
ros, kai ranka atitraukta nuo kūno 90 laipsnių ir sulenkta per alkūnę. Peties sukamųų raumenų maksimali izometrinè jèga testuota rankiniu dinamometru (Lafayette manual muscle testing system, model 01165) gulint ant nugaros, kai žastas atitrauktas 90 laipsnių, neutralioje padètyje ir ranka sulenkta per alkūnès sąnarị 90 laipsnių. Dinaminiam peties sąnario stabilumui ịvertinti naudoti viršutinès galūnès dinaminio stabilumo testas bei uždaros kinematinès grandinès stabilumo testas viršutinei galūnei.

Duomenų analizè atlikta naudojant statistinès analizès IBM SPSS Statistics 23.0 ir Microsoft Office Excel 2018 programas. Pagal aritmetinius vidurkius ir standartinius nuokrypius bei paklaidas buvo tikrinamas tyrimo duomenu statistinis reikšmingumas. Rodikliams, kurie atitiko normalumo sąlygą, priklausomų imčių vidurkių palyginimui naudojamas t-kriterijus priklausomoms imtims, nepriklausomų imčių palyginimui - Student (t) testas. Normalumo sąlygos neatitikusiems rodikliams taikytas Wilcoxon ženklų kriterijus priklausomoms imtims ir Mann-Whitney Wilcoxon - nepriklausomoms imtims. Koreliaciniams ryšiams tarp normalumo sąlygos netenkinančių rodiklių

3 lentelè. Viršutinès galūnès dinaminio stabilumo testo dominuojančios pusès rezultatų palyginimas tarp tiriamųjų grupių $p$ - reikšmingumo lygmuo, $S N$ - standartinis nuokrypis

\begin{tabular}{|l|c|c|c|}
\hline $\begin{array}{l}\text { Dinaminio stabilumo } \\
\text { testo rezultatai }\end{array}$ & $\begin{array}{c}\text { Skausmą jau- } \\
\text { čiančių grupė } \\
\text { (vidurkis } \pm \text { SN) }\end{array}$ & $\begin{array}{c}\text { Skausmo } \\
\text { nejaučian- } \\
\text { čių grupè } \\
\text { (vidurkis } \pm \text { SN) }\end{array}$ & $\boldsymbol{p}$ \\
\hline $\begin{array}{l}\text { Priekinis nuokrypis, } \\
\text { cm }\end{array}$ & $57,46 \pm 7,64$ & $61,78 \pm 10,00$ & 0,130 \\
\hline $\begin{array}{l}\text { Vidurinis nuokrypis, } \\
\text { cm }\end{array}$ & $68,12 \pm 9,64$ & $75,04 \pm 10,34$ & 0,035 \\
\hline Išorinis nuokrypis, cm & $81,76 \pm 8,79$ & $85,06 \pm 9,06$ & 0,250 \\
\hline $\begin{array}{l}\text { Kombinuotas rezul- } \\
\text { tatas }\end{array}$ & $76,03 \pm 7,22$ & $81,95 \pm 6,86$ & 0,012 \\
\hline
\end{tabular}

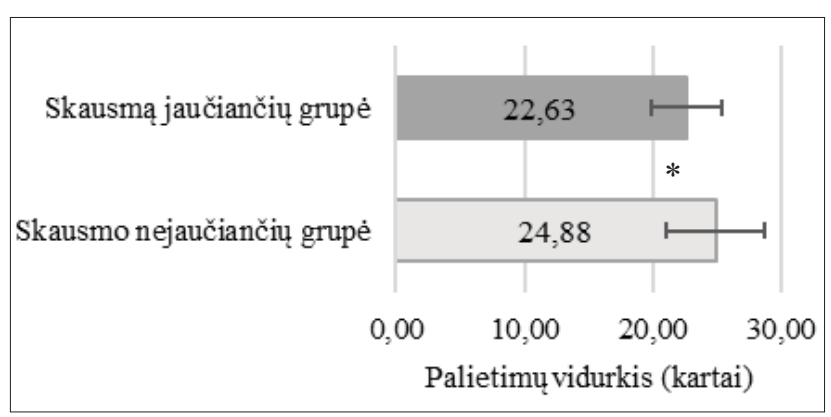

2 pav. Uždaros kinematinès grandinès dinaminio stabilumo testo viršutinèms galūnėms rezultatų vidurkių palyginimas tarp tiriamuju grupių

* - statistiškai reikšmingas skirtumas tarp grupiu $(p<0,05)$ skaičiuoti naudojamas Spearmen koreliacijos koeficientas. Rezultatai vertinami kaip statistiškai reikšmingi, jei $\mathrm{p}<0,05$.

\section{Rezultatai ir jų aptarimas}

Iš visų tyrime dalyvavusių tinklininkų 21 jautẻ lètinị, ilgiau nei tris mėnesius trunkanti peties skausmą, tačiau ir toliau žaide tinklinį mažiausiai vieną, daugiausiai keturis kartus per savaitę. Daugumos dalyvavusių tyrime žmonių dominuojanti ranka buvo dešinè, tik keturių - kairè (po du kiekvienoje grupeje). Skausmą jaučiančių ir nejaučiančių tiriamuju grupès statistiškai reikšmingai nesiskyrè pagal lytị, amžių, ùgị ir svorị ( $p>0,05)$ (1 lentelè). Tiriamieji, kurie jaute skausmą, vidutiniškai per savaitę treniravosi trumpiau ir turejo mažesnę žaidimo patirtį, tačiau skirtumas tarp grupių buvo statistiškai nereikšmingas ( $\mathrm{p}>0,05)$.

Palyginus dominuojančios rankos peties sąnario amplitudžių vidurkius, pastebeti skirtumai tarp tiriamųų grupių rezultatų (2 lentelè). Visos amplitudès buvo mažesnès skausmą jaučiančių grupejje, tačiau statistiškai reikšmingas $(p<0,05)$ vidurkiu skirtumas, 6,5 laipsnio, buvo pastebetas tik atliekant žasto sukimą i vidų. Pasak D. Challoumas, A. Stavrou ir bendraautorių (2017), žasto sukimo ị vidų amplitudès sumažèjimas skausmą jaučiančių grupejje galèjo išsivystyti dèl didesnio užpakalinès peties sąnario kapsulès ịsitempimo, hipertrofijos ar peties ankštumo sindromo, kurie susiję su žasto ị vidų sukamụjų raumenų sausgyslių pažeidimais [8].

Panašiai kaip ir šiame tyrime, R. Keller ir bendraautorių (2018) metaanalizèje teigiama, kad sukimo ị vidų sumažèjimas yra susijęs su viršutinès galūnès traumomis, kurias patiria daug judesių virš galvos rankomis atliekantys sportininkai [9].

Peties sąnario stabilizacijai smūgiavimo ar kamuolio padavimo metu reikalinga pakankama sukamosios manžetès raumenų jẻga ir tarpraumeninè koordinacija. Palyginus žasto vidinių ir išorinių sukamųjų raumenų izometrinę jẻgą tarp grupių, buvo pastebèta, kad skausmą jaučiančių tinklininkų rezultatai mažesni (1 pav.). Statistiškai reikšmingas skirtumas rastas tarp žasto išorinių sukamųų raumenų jègos $(p<0,05)$. Y. Shih ir bendraautorių (2019) tyrime palyginus izometrinès jègos rezultatus tarp kontrolinès ir traumuotų (jautusių peties skausmą per paskutinius šešis mėnesius) tinklininkų grupių, statistiškai reikšmingų skirtumų nebuvo, tačiau kontrolinėje grupejje buvo didesnè visų testuotų raumenų jèga [10], kaip ir mūsų tyrime skausmo nejaučiančių tinklininkų grupèje. Nèra įrodyta, kad tinklininkų dominuojančios pusès išorinių sukamujų raumenų silpnumas didina traumų riziką, tačiau kitose sporto šakose, kuriose atliekama daug judesių pakeltomis rankomis, tokiose kaip rankinis ar beisbolas, išoriniu sukamujų raumenų jègos sumažèjimas laikomas vienu iš veiksnių, turinčių sąsajų su peties skausmu [11]. Pagal D. 
Challoumas, A. Stavrou ir bendraautorių (2017) analizès išvadas, pagrindinis tinklininkų peties skausmo ir traumų rizikos veiksnys yra dominuojančios rankos žasto sukamujų raumenu jègos disbalansas, kadangi peties funkcijoms atlikti reikalinga apylygė antagonistinių raumenų grupių jèga [8]. Mūsų tyrime gautas santykis (vidutinę žasto išorinių sukamujų raumenų jẻgą padalinus iš vidinių sukamųų raumenų jëgos) statistiškai reikšmingai nesiskyrè tarp grupių. Skausmo nejaučiančių tinklininkų šių raumenų antagonistų santykis buvo lygus 0,86 ir didesnis už kitos grupès, kurioje jo vertè siekè 0,80 . Jei į vidų sukamujų raumenų jèga didesnè už sukamujų ị išorę daugiau nei trečdaliu, tai peties sąnario stabilizacija atliekant judesius gali būti sutrikusi [8].

Dominuojančios pusès peties dinaminè pusiausvyra ir stabilumas skyrèsi tarp tiriamujų grupių (3 lentelè). Skausmo nejaučiančių tinklininkų grupè dinaminio stabilumo ir pusiausvyros (angl. Upper quarter Y balance) testo metu pasiekè didesnius atstumus ir pasiekė aukštesnị kombinuotą rezultatą. Statistiškai reikšmingas skirtumas tarp grupių buvo gautas testuojant vidurinio nuokrypio kryptyje pasiekiamą atstumą ( $p<0,05)$, kuris skyrèsi 6,92 centimetrais, kai suskaičiavus kombinuotą rezultatą $(p<0,05)$, skirtumas tarp grupių buvo 7,22 procentai.

Statistiškai reikšmingas skirtumas $(p<0,05)$ tarp skausmą jaučiančių ir nejaučiančių tinklininkų buvo pastebetas ir vertinant uždaros kinematinès grandinès stabilumo testą, skirtą viršutinèms galūnėms (angl. CKUEST) (1 pav.). Per 15 sekundžių uždaros kinematinès grandinès dinaminio stabilumo testo metu skausmo nejaučiančių grupès tiriamieji vidutiniškai 2,25 palietimais daugiau pasiekè priešingą ranką ( 2 pav.). Pasak R. Westrick ir bendraautorių, aukštesni dinaminio stabilumo testavimo rezultatai reiškia geresnę peties, viršutinès galūnès ir viso raumeninio korseto stabilizacinę funkciją bei mobilumą [12]. Kaip pateikiama L. Cosio-Lima ir bendraautorių (2016) tyrime, žemesni viršutinès galūnès dinaminio stabilumo ir pusiausvyros testo rezultatai siejami su didesne traumų rizika, todèl tai tinkama priemonè tirti galimus lètinius pažeidimus [13].

Tyrime skausmą jaučiančių grupejje atlikti trys provokaciniai testai peties ankštumo sindromo požymiams tirti: Hawkins-Kennedy, „Tuščios skardinès“ ir Neer. Jų metu tiriamieji pateikè skausmo stiprumą balais pagal VAS skalę. Statistiškai reikšminga vidutinio stiprumo neigiama koreliacija ( $r=-0,447, p=0,042)$ nustatyta tarp žasto sukimo ị vidu ir „Tuščios skardinès“ testo VAS rezultatų: kuo stipresni skausmą jautè tiriamasis, tuo mažesnè buvo jo pasiekta judesio amplitudè. Nors R. Keller ir kitų autorių (2018) metaanalizèje teigiama, kad sumažejusi žasto sukimo ị vidų amplitude gali būti siejama su peties traumomis, tačiau statistiškai reikšmingų koreliacijų nebuvo rasta [9]. Vidutinio stiprumo statistiškai reikšminga koreliacija $(r=-0,592, p=0,005)$ nustatyta tarp Neer testo ir žasto lenkimo. Kuo mažesnè buvo tiriamojo žasto lenkimo amplitudè, tuo stipresnis skausmas buvo provokuojamas. Pasak R. Sutaria ir kitų (2017), šis judesio ribojimas išsivysto dèl viršdyglinio raumens sausgyslių pažeidimo ar popetinio tepalinio maišelio uždegimo [14].

Siekiant išvengti lètinio skausmo ar traumų, rekomenduojama reguliariai įvertinti tinklininkų funkcinę būklę, atkreipiant dèmesị ị šiuos rodiklius: žasto sukimo ị vidų ir ị išorę bei lenkimo amplitudes, išorinių ir vidinių sukamujjų raumenų jègą ir jos santykị, peties sąnario dinaminị stabilumą.

\section{Išvados}

1. Dominuojančios rankos žasto sukimo ị vidų amplitude, išorinių sukamųų raumenų izometrinè jèga bei peties sąnario dinaminio stabilumo testų rezultatai buvo mažesni skausmą jaučiančių tinklininkų grupejje.

2. Rastos sąsajos tarp peties skausmo stiprumo klinikinių provokacinių testų metu ir žasto judesių amplitudžių (lenkimo ir sukimo ị vidų).

\section{Literatūra}

1. Seminati E, Minetti AE. Overuse in volleyball training/practice: A review on shoulder and spine-related injuries. Eur J Sport Sci 2013; 13(6):732-43.

https://doi.org/10.1080/17461391.2013.773090

2. Cools AMJ, Vanderstukken F, Vereecken F, Duprez M, Heyman $\mathrm{K}$, Goethals N, et al. Eccentric and isometric shoulder rotator cuff strength testing using a hand-held dynamometer: reference values for overhead athletes. Knee Surgery, Sport Traumatol Arthrosc 2016;24(12):3838-47.

https://doi.org/10.1007/s00167-015-3755-9

3. Cools AMJ, Reeser JC. Shoulder injuries in volleyball. In: Reeser JC, Bahr R, editors. Handb Sport Med Sci Volleyb 2017: 93-108.

https://doi.org/10.1002/9781119227045.ch8

4. Reeser JC, Joy EA, Porucznik CA, Berg RL, Colliver EB, Willick SE. Risk factors for volleyball-related shoulder pain and dysfunction. PM\&R 2010;2(1):27-36. http://www.sciencedirect.com/science/article/pii/S1934148209015962

https://doi.org/10.1016/j.pmrj.2009.11.010

5. Borms D, Cools A. Upper-extremity functional performance tests: reference values for overhead athletes. Int J Sports Med 2018;39(6):433-41.

https://doi.org/10.1055/a-0573-1388

6. Cramer J, Quintero M, Rhinehart A, Rutherford C, Nasypany A, May J, et al. Exploration of score agreement on a modified upper quarter Y-balance test kit as compared to the upper quarter Y-balance test. Int J Sports Phys Ther 2017;12(1):117-24. http://www.ncbi.nlm.nih.gov/pubmed/28217422\%0A http://www.pubmedcentral.nih.gov/articlerender. 
rtid=PMC5294938

7. Kilic O, Maas M, Verhagen E, Zwerver J, Gouttebarge V. Incidence, aetiology and prevention of musculoskeletal injuries in volleyball: a systematic review of the literature. Eur J Sport Sci 2017;17(6):765-93. https://doi.org/10.1080/17461391.2017.1306114

8. Challoumas D, Stavrou A, Dimitrakakis G. The volleyball athlete's shoulder: biomechanical adaptations and injury associations. Sport Biomech Scotland 2017;16(2):220-37. https://doi.org/10.1080/14763141.2016.1222629

9. Keller RA, De Giacomo AF, Neumann JA, Limpisvasti O, Tibone JE. Glenohumeral internal rotation deficit and risk of upper extremity injury in overhead athletes: a metaanalysis and systematic review. Sports Health United States 2018;10(2):125-32. https://doi.org/10.1177/1941738118756577

10. Shih Y-F, Wang Y-C. Spiking kinematics in volleyball players with shoulder pain. J Athl Train 2019;54(1):90-98. http://www. ncbi.nlm.nih.gov/pubmed/30657718\%0Ahttp://natajournals. org/doi/10.4085/1062-6050-216-17 https://doi.org/10.4085/1062-6050-216-17

11. Myklebust G, Andersson SH, Munk R, Bahr R, Clarsen B. Reduced glenohumeral rotation, external rotation weakness and scapular dyskinesis are risk factors for shoulder injuries among elite male handball players: a prospective cohort study. Br J Sports Med 2014;48(17):1327-33. https://doi.org/10.1136/bjsports-2014-093702

12. Westrick RB, Miller JM, Carow SD, Gerber JP. Exploration of the Y-balance test for assessment of upper quarter closed kinetic chain performance. Int J Sports Phys Ther 2012;7(2):139-47.

13. Cosio-Lima L, Knapik JJ, Shumway R, Reynolds K, Lee Y, Greska E, et al. Associations between functional movement screening, the $\mathrm{Y}$ balance test, and injuries in coast guard training. Mil Med 2016;181(7):643-8.

https://doi.org/10.7205/MILMED-D-15-00208

14. Sutaria RG, Sutaria RB. Subacromial bursitis and impingement BT - musculoskeletal sports and spine disorders: a comprehensive guide. In: Kahn SB, Xu RY, editors. Cham: Springer International Publishing 2017:51-4.

https://doi.org/10.1007/978-3-319-50512-1_10

\section{SHOULDER PAIN RELATIONSHIP WITH DOMINANT SHOULDER ROM, ROTATOR CUFF ISOMETRIC STRENGTH AND DYNAMIC STABILITY AMONG VOLLEYBALL PLAYERS \\ G. Kurtinaityte, A. Jakubauskienè}

Keywords: volleyball, dominant side, shoulder injuries, pain, injury prevention.

Summary

The aim of this research was to analyse the relationship between the pain within the dominant shoulder of volleyball players and these shoulder characteristics: the ROM, the isometric strength of internal and external rotators', and its dynamic stability. The subjects of the study were 40 recreational volleyball players (age $28,45 \pm 7,55$ years, sport experience $8,65 \pm 5,34$ years) that were divided into two groups based on the survey data: those with $(n=21)$ and without $(n=19)$ pain in the shoulder area. We measured the active shoulder range of motion (flexion, internal and external rotation), maximum isometric force of shoulder rotator muscles, Upper quarter Y Balance test and Kinetic Chain Upper Extremity Stability Test of the dominant shoulder. During the clinical provocative tests (Hawkins-Kennedy, Neer, Empty can), the intensity of the pain experienced by one of the groups was assessed by the visual analogue scale (VAS). A statistically different results $(\mathrm{p}<0.05)$ have been observed between this group and the controls, both for the dominant shoulder internal rotation active range of motion, as well as the isometric strength of external rotator muscles. Internal rotation AROM and maximum isometric force of external rotators were lower in the group with shoulder pain. Significantly better results were achieved by the group without shoulder pain when performing upper extremity balance and dynamic stability tests . In conclusion, volleyball players' dominant shoulder AROM, isometric strength and dynamic stability is lower when experiencing shoulder pain. There is a relation between the shoulder pain intensity experienced by volleyball players and the dominant side internal rotation as well as flexion ROM.

Correspondence to: gaivile.k@gmail.com

Gauta 2020-01-23 